\title{
Examination of Wrestling Athletes' Psychological Resilience in Terms of Wrestling Education
}

\author{
Mehmet Emre Eryücel \\ Faculty of Sport Sciences, Akdeniz University, Turkey
}

Copyright $\subseteq 2019$ by authors, all rights reserved. Authors agree that this article remains permanently open access under the terms of the Creative Commons Attribution License 4.0 International License

\begin{abstract}
The aim of this study is to examine the psychological resilience levels of the individuals engage in wrestling and age, gender, education level, year of wrestling, parental attitudes and harmful habit variable sand the relationship between the level of psychological resilience of the athletes based on wrestling education. The study is limited with athletes who engage in wrestling in the city of Antalya. It consists of a total of 150 participants, among which 24 of them are females, and 126 of them are males. In order to identify the resilience levels of the athletes, which are the dependent variable of the study, "Resilience Scale for Adults" developed by Fribog et al. (2005) and adapted into Turkish by Basım and Çetin (2011) by checking its validity and reliability was used. By utilizing the variables of age, gender, educational status, years spent in playing wrestling, harmful habit, and perceived parental attitudes, their descriptive statistical averages are checked. As a result of the study, the mean score for psychological resilience is 125,88 . Scores of female participants regarding resilience are seen to be higher compared to males. In terms of years spent in playing wrestling, there is a significant difference in positive direction. Resilience scores of individuals who have bad habits have higher scores compared to individuals who do not have bad habits. As for perceived parental attitude, it is seen that resilience scores of individuals whose parents are caring are higher compared to the ones whose parents are not caring. It may be useful to construct wrestling education in the light of these data.
\end{abstract}

Keywords Psychological Resilience, Wrestling and Wrestling Education

\section{Introduction}

Sport is a competitive, cooperative, and a cultural phenomenon developing the soul and the body of individuals, unifying communities, socializing the individual, transforming the natural environment of individuals into a social environment, developing their obtained skills, and exercised with or without instruments based on certain rules (Kılc1gil, 1985).

Today, it is known that sport is an important educational tool that improves the social harmony, mental and physical health of the individual (Bayköse et al., 2016; Kiliç, Bayköse \& Kaplan, 2018; Bayköse et al., 2017b). Furthermore, sport includes an element of a desire to win a competition in its essence, and as it preserved this essence of winning during its development processes is also regarded as a full-time business apart from being a leisure time activity, which means it may also be adopted by individuals as a profession (Fişek, 1983).

In the case of performance in sports education, it is also important to manage this. According to Erdal (2012), performance management in sport is rather significant in terms of increasing the success of the athlete, facilitating control, enhancing social welfare, strengthening competition, increasing quality, and ensuring the enhancement of organization.

As a result of qualitative analyses, researchers found that high sportive trust increases performance by way of the positive effect of trust on opinions, emotions, and behaviors of athletes. It was found that high sportive trust especially equals to effective cognition (i.e., focusing on the task), positive affection (i.e., enjoyment), and effective behaviors (i.e., confident body language) (Bülbül, 2015; Fletcher \& Sarkar, 2012).

In this sense, well-structured sports education can be very useful for young and children, even adults and elderly people.

\section{Resilience}

All individuals may encounter difficult life incidents during their lifespan. While some of these incidents could be natural disasters, others may be incidents that may have drastic changes on the lifestyle of the individual such as the loss of a beloved person or the divorce of parents (Fletcher, Sarkar, \& Bülbül, 2015). While some individuals may easily adapt life against these difficult life incidents to 
continue their lives as usual, others may have difficulty in adapting. Therefore, the concept of psychological resilience is revealed corresponding to a process necessitating the individual to demonstrate behaviors for adaptation and for struggling against these difficult life incidents (Masten, 2001).

In recent years, the concept of resilience in behavioral sciences has seen a profound interest as a personality trait supporting individuals to cope with incidents and reducing stress (Bayköse, Civar Yavuz, Keskin \& Kilinç, 2017a). This interest has shown itself in the scope of conceptual analyses and studies (Sezgin, 2012). Although there are a great number of definitions for the concept of resilience, each definition covers a different characteristic of the concept. Fletcher and Sarkar (2012), Bülbül, (2015), in their literature review, discussed the common points of these definitions, and resilience as a personality trait was used to define the assumption that it is a characteristic or a personal skill allowing individuals to overcome difficulties despite the presence of unfavorable conditions and to stay standing by showing a better development than the expected behaviors. Life stories of famous or successful individuals are associated with this fundamental concept even though they grew up under difficult living conditions. This association is in line with findings of systematic resilience studies aiming to identify the variables that may lead both individuals and groups under high risk to obtain successful outcomes. Second fundamental resilience characteristic shows the ability of the individual to rapidly adapt against a stressful life. In this kind of resilience studies, basic stress factor such as divorce or conflict in the family was taken as the focal point.

Third characteristic of resilience refers to overcoming situations of trauma such as experiencing natural disasters, losing a highly beloved person, or experiencing accidents. Psychological resilience is generally explained by outcomes and reasons resulting from these outcomes. These variables are classified under three main points in the literature: (1) Risk factor, (2) protective factors, and (3) positive outcomes (Bülbül, 2015; Coleman, Coleman \& Hagell, 2007; Rutter, 2015).

Risk Factors: Risk, as a variable that predicts possible negative outcomes, is used to refer to negative life conditions. Risk factors are classified into three groups as the ones related to individuals (such as low intelligence levels, anxious temperament, experiencing health problems, low self-confidence of the individual, individual's difficulty in effectively expressing himself/ herself, or having an aggressive personality structure), the factors related to family (such as familial health problems, divorce of parents, having a single parent, lack of healthy and regular communication between parent and child, too harsh or inconsistent disciplinary approach, negative relationships between the siblings, domestic violence, family neglect, and abuse), and social risk factors (such as low socioeconomic level, insufficiency of the house, school or other services, lack of positive social role models, use of drugs, migration, and unemployment) (Tümlü \& Recepoğlu, 2013).

Protective Factors: Protective factors refer to situations reducing or eliminating the effect of the risk or challenge, and allowing individuals to develop the healthy adaptations or their competences (Bülbül, 2015; Masten, Masten, 2001). The presence of protective factors in the individual's, while preventing the emergence of a problem and reducing the possibility of a problematic behavior to develop, assist the individual to strengthen behaviors, attitudes, and information that may contribute to the emotional and physical well-being by reducing the effect of an existing problem, and to allow these individuals to show resistance against the difficulties. Studies about resilience classifies protective factors into two groups as inner factors (such as having close relationships between parents and other adults, having trustworthy parents, presence of positive family climate, presence of an orderly house environment, high educational levels of parents, supporting education, having socioeconomic advantages, presence of responsible and conformist friends, presence of an effective school, presence of connection with social organizations, presence of social security).

Positive Outcomes: These are competencies of individuals obtained as a result of overcoming the risk factors by way of inner and outer protective factors. These outcomes may be such positive outcomes as the fulfillment of development tasks of individuals, presence of academic achievement, positive social relationships/ social competence, keeping away from behaviors towards crime, scarcity of psychological problems or symptoms, happiness, regularly attending school, participation in social welfare activities, participation in extracurricular activities, demonstrating common courtesy behaviors, adoption by friends, absence of psychopathology, self-acceptance and harmony, well-being, and satisfaction with life (Tümlü \& Recepoğlu, 2013).

Resilience generally refers to a process of adaptation or achievement (Hunter, 2001). Within this scope, resilience can be regarded as the individual process of adaptation against the important sources of stress such as trauma, a tragedy or familial or relational problems, serious health problems, workplace or financial problems (Bülbül, 2015; Tusaie \& Dyer, 2004). On the other hand, resilience is defined as the power to pulling oneself together against difficult life experiences (Garmezy, 1991), or the ability to successfully overcome a drastic change or a disaster (Bülbül, 2015; Eryücel, 2018; Wagnild, 2009).

Even though it is possible to mention a great number of factors playing a role in explaining resilience, it is argued that these factors may be classified under three general categories (Haase, 2004). These categories can be limited as family cohesion and support, personal structural characteristics, and outer support systems (social environment, colleagues, peers, etc.) Personality traits are 
characteristics such as physical power, sociability, intelligence, communicative skill, self-sufficiency, and skills (Bülbül, 2015; Olsson et al., 2014). Studies focusing on familial characteristics, on the other hand, demonstrate that the relationship between with at least one parent or someone who substitutes the parent is significant (Bülbül, 2015; De Haan, Hawley \& Deal, 2002; Eryücel, 2018; Fonagy, 1994). Outer support systems increasing resilience may include friends, teachers, neighbors and other people who assist individuals' efforts to overcome challenges (Brooks, 1994; Bülbül, 2015). Furthermore, it is also seen that the presence of people outside the family supporting the individual against difficult conditions is also important apart from the presence of a supportive educational environment as social interaction and cooperation are regarded as necessary in the process (Bülbül, 2015; Smith \& Prior, 1995).

\section{Method}

The aim of this study is to test the resilience of 150 individuals engaging in the sport of wrestling with factors such as age, gender, educational level, years of wrestling, harmful habits, and parental attitudes.

Although there are a great number of resilience studies in a variety of fields, these studies have generally been conducted on children, adults, and familial problems that these adults have experienced during their childhood years (Greff, 2004). This study bears importance in terms of demonstrating the resilience levels of athletes engaging in wrestling. Today, psychological processes, which are amongst the commonly encountered disorders, are seen to be among the problems of which the athletes avoid the most. Therefore, it is important to demonstrate the importance and practicality of the developmental processes of athletes and their sociocultural and socioeconomic levels in terms of resilience. In short, it is possible to claim that the levels of resilience necessary for the developmental processes of athletes are in line with the emergence of positive behaviors and the success of athletes.

\subsection{Measuring Tools}

\section{Resilience Scale for Adults}

Resilience scale for adults was developed by Friborg et al. (2005). The sub-dimensions of the scale consisting of six sub-dimensions are as follows: Perception of self, perception of future, structured style, social competence, social resources, and family cohesion. There are spaces between the expressions in the scale, and there are five checkboxes between the statements to be filled. The boxes are checked according to the degree of affinity to either statement. There are positive statements on the one hand and negative statements on the other; and while high score refers to high resilience, low score refers to low resilience as a result of the scoring. The dimensions are measured according to a different number of items. High scored indicates that the tendency towards the related dimension increase. The scale was translated and appropriated into Turkish by Basım and Çetin (2011). Structural validity test of the scale was conducted on Amos 16.0 software, and confirmative factor analysis was conducted using maximum likelihood technique. As a result of the confirmative factor analyses conducted for the six dimension factor structure of the scale, the ratio of chi-square statistic on degrees of freedom was calculated as $\left(\chi^{2} / \mathrm{df}\right) 2,1\left(\chi^{2}=1008, \mathrm{df}=480,\right)$; root mean square error (RMSEA) as 0,053 ; Tucker-Lewis Index (TLI) value as 0,91 , and comparative fit index (CFI) value as 0,92 ). For the reliability analysis of the scale, test-retest, test reliability, and internal consistency were employed. As a result of test-retest, Pearson Correlation Coefficients of sub-dimensions were found to be $0,72 \quad(p<0,01)$ for Perception of Self, $0,75(\mathrm{p}<0,01)$ for Perception of Future, $0,68(\mathrm{p}<0,01)$ for Structured Style, 0,78 $(\mathrm{p}<0,01)$ for Social Competence, $0,81(\mathrm{p}<0,01)$ for Family Cohesion, and $0,77(\mathrm{p}<0,01)$ for Social Resources (Basım \& Çetin, 2011: 109). Total Cronbach Alpha coefficient of the scale was measured to be 0,86 (Basım \& Çetin, 2011). In the factor analysis employing Maximum Likelihood analysis method and Varimax axis rotation technique, initially $\mathrm{KMO}$ and Bartlett's test was conducted, and sampling adequacy was found as 0,812 , and Bartlett normal distribution test result was found to be significant $(\mathrm{p}<0,01)$. Furthermore, as a result of factor analysis, a six-factor structure was revealed, which has an eigenvalue above one. This structure shows similarity with the original scale. Examining the items generated under the factors, it was also seen that all six factors are entirely the same. As a result, in consequence of exploratory factor analysis utilized to test the structural validity values of the Resilience Scale, its six-factor structure was found to be suitable to be used within the framework of this study.

\subsection{Analysis of Data}

Descriptive information of the participants is given as percentage and frequency. During the analysis of data, T-Test, One-Way Analysis of Variance (ANOVA), and Pearson Correlation Analysis were conducted. Statistical analysis was conducted using SPSS 22 Package Software. Significant level was regarded as 0,05 . As a result of the factor analysis applied for this study, six-factor structure consisting of "Perception of Self", "Perception of Future", "Structured Style", "Social Competence", "Family Cohesion", and "Social Resources" was verified $\left(\chi^{2}=1104\right.$, $\mathrm{df}=480, \chi^{2} / \mathrm{df}=2,3$; RMSEA $=0,055$; TLI $=0,90 ; \mathrm{CFI}=0,91$ ). For the validity of criterion dependent validity, Social Comparison Scale and Locus of Control Scale were utilized. It was found that the alpha coefficients of the sub-dimensions of the scale vary between 0,66 and 0,81 , 
and their test-retest reliability varies between 0,68 and 0,81 .

\section{Findings}

While $16 \%$ of the 150 participants engaging in wrestling as a sport were females, $84 \%$ of them are males. The youngest of the 150 participants is 13 years old while the oldest one is 27 . Average age of the participants is 17 . The lowest number of year spent engaging in wrestling by the participants is 1 , while the highest number of years is 18 . Average years of wrestling is 5,24 years. As for educational levels of the participants, 1 person has no education corresponding to $0,7 \%, 6$ people are primary school graduates corresponding to $5 \%, 102$ people are high school graduates corresponding to $68 \%$, and 41 people are university graduates corresponding to $27,3 \%$. Among the participants, 15 people have harmful habits which correspond to $10 \%$, and 135 people do not have harmful habits corresponding to $90 \%$. Lastly, among the participants 144 of their parents are caring, constituting $96 \%$ of the participants and 6 of their parents are not caring, constituting the $4 \%$.

Table 1. Average Scores of Resilience

\begin{tabular}{lr}
\hline \multirow{2}{*}{ Total } & 150 \\
\cline { 2 - 2 } & 0 \\
\hline Average & 125,8800 \\
\hline Median & 125,5000 \\
\hline Mode & 136,00 \\
\hline Standard Deviation & 20,19799 \\
\hline Lowest Value & 89,00 \\
\hline Highest Value & 165,00 \\
\hline
\end{tabular}

In Table 1, among 150 participants engaging in wrestling as a sports activity, the lowest score is 89 while the highest score is 165 . Average score of resilience is 125,88 .

Table 2. Average Scores of Resilience According to Gender

\begin{tabular}{ccccc}
\hline & Gender & Number & Average & $\begin{array}{c}\text { Standard } \\
\text { Deviation }\end{array}$ \\
\hline $\begin{array}{c}\text { Average Score of } \\
\text { Resilience }\end{array}$ & Female & 24 & 128,0000 & 23,32194 \\
\cline { 2 - 5 } & Male & 126 & 125,4762 & 19,62599 \\
\hline
\end{tabular}

In Table 2, among 150 participants engaging in wrestling as a sports activity, average resilience score of female participants is 128 , while it is 125,47 for male participants. It is identified that the average score of female participants is 2,53 higher than that of the males.
Table 3. Relation Between Years in Wrestling and Resilience

\begin{tabular}{cccccc}
\hline & Average & $\begin{array}{c}\text { Standard } \\
\text { Deviation }\end{array}$ & t & df & sig \\
\hline $\begin{array}{c}\text { Years in } \\
\text { Wrestling-Average } \\
\text { Score of Resilience }\end{array}$ & $-120,63333$ & 19,18172 & $-77,024$ & 149 &, 000 \\
\hline & Total & Correlation & Sig. \\
\hline $\begin{array}{c}\text { Years in Wrestling } \\
\text { and Average Score of } \\
\text { Resilience }\end{array}$ & 150 &, 345 &, 000 \\
\hline
\end{tabular}

In Table 3, there is a significant relationship between the years spent in wrestling and average score of resilience for the 150 participants (p: ,000). Statistically significant difference on a negative direction was found between years spent in wrestling and average score of resilience $(\mathrm{p}<0,005)$.

Table 4. Average Scores of Resilience According to Education Levels

\begin{tabular}{cccc}
\hline & Number & Average & $\begin{array}{c}\text { Standard } \\
\text { Deviation }\end{array}$ \\
\hline Uneducated & 1 & 140,0000 & \\
\hline Primary School & 6 & 108,3333 & 20,97300 \\
\hline High School & 102 & 124,3039 & 19,86628 \\
\hline University & 41 & 132,0244 & 19,28534 \\
\hline Total & 150 & 125,8800 & 20,19799 \\
\hline
\end{tabular}

On Table 4, the effect of educational levels of 150 participants on resilience was examined, and the lowest average score is of primary school graduates with 108,33, and the highest score is of the participants without education with 140 .

Table 5. Average Score of Resilience Scale According to Harmful Habits

\begin{tabular}{ccccc}
\hline & Number & Average & $\begin{array}{c}\text { Standard } \\
\text { Deviation }\end{array}$ \\
\hline $\begin{array}{c}\text { Average } \\
\text { Score of Resilience }\end{array}$ & $\begin{array}{c}\text { There is a } \\
\text { harmful habit. }\end{array}$ & 15 & 130,8667 & 20,85620 \\
\hline $\begin{array}{c}\text { There is no } \\
\text { harmful habit. }\end{array}$ & 135 & 125,3259 & 20,12677 \\
\hline
\end{tabular}

In Table 5, 15 people have harmful habits among 150 participants engaging in wrestling as a sports activity, and their average score of resilience is 130,86 . It was found that individuals with harmful habits (such as smoking etc.) have a higher average score of resilience.

Table 6. Average Score of Resilience Scale According to Perceived Parental Attitudes

\begin{tabular}{ccccc}
\hline & & Number & Average & $\begin{array}{c}\text { Standard } \\
\text { Deviation }\end{array}$ \\
\hline $\begin{array}{c}\text { Average Score of } \\
\text { Resilience }\end{array}$ & Caring & 144 & 126,7014 & 20,08795 \\
\cline { 2 - 5 } & Not Caring & 6 & 106,1667 & 11,42658 \\
\hline
\end{tabular}


In Table 6, among 150 participants engaging in wrestling, 140 people's parental attitudes are caring with an average score of 126,70 while 6 people's parents are not caring with an average score of 106,16.

Table 7. Relation Between Resilience and Age

\begin{tabular}{cccc}
\hline & Total & Correlation & $\mathrm{p}$ \\
\hline $\begin{array}{c}\text { Average Score of } \\
\text { Resilience and Age }\end{array}$ & 150 &, 257 &, 001 \\
\hline
\end{tabular}

In Table 7, it is identified that there is a statistically positive and significant relationship between the average resilience score of 150 participants engaging in wrestling as a sport activity and their ages.

\section{Discussion}

Throughout the study, personality traits of athletes engaging in wrestling in Antalya were taken into consideration. Independent variables, which are the subject of examination in the study, were taken into consideration by the researcher, and included in the personal information form created by the researcher. In this sense, gender, age, education level, year of wrestling sport, harmful habits and parental attitudes were examined in the context of variables that could explain the relationship between wrestling education and psychological resilience.

According to the findings of the study, it is seen that the resilience scores of female athletes who are engaging in wrestling as a sports activity are higher. While reviewing the literature, it is possible to find studies that are the equivalent of this study. In Bülbül's (2015) study on basketball and tennis players, it was identified that resilience score of female participants was significantly higher compared to male participants of the study. However, the number of female wrestlers is low both in this study and in the literature compared to the number of males. The reason for the difference in the average scores of gender may be the fact that the number of female participants is lower. Furthermore, a significant difference between genders was not found. There is a significant difference with a positive correlation between the years of wrestling spent by the participants and their average scores of resilience scale. This is considered as one of the positive contributions of engaging in sports activities. There is a difference between the educational levels of participants and their psychological resilience. The lowest average score corresponds to primary school graduates with 108,33 while the highest level is obtained by the participants without education with 140. Reviewing the literature, any study explaining the resilience of wrestlers and educational status was not found. However, it is at times possible to encounter studies demonstrating a negative relationship between educational status and other psychological variables. Moreover, one can also encounter studies emphasizing the negative relation between resilience and education. The reason why the resilience scores of highly educated individuals are higher may be explained by the possibility that their expectations are high, and education may predict their psychological vulnerability.

Resilience scores of individuals who have harmful habits were found to be higher compared to individuals who do not have harmful habits. The average resilience score of individuals with harmful habits is 130,86 while the average score for individuals without harmful habits is 125,32. Çataloğlu (2011), in her study, demonstrated that individuals who do not use drugs are able to perceive problem-solving, emotional reactions, self-awareness functions more healthily compared to individuals who use drugs. From this perspective, the data that we obtained and the revealed results do not show parallelism with the literature. However, it is also possible to assume that harmful behaviors reduce stress as there's a belief that they may relieve during challenging incidents.

As for perceived parental attitudes, the average scores for caring parental attitude is 126,7 while not caring parental attitude is 106,4 . The fact that the participants are cared for by their families positively affects their psychological resilience. When looking at the literature, it is possible to find equivalent studies. Therefore, it is possible to interpret this situation as the autonomy decreases with the increase in family support, and with the increase of autonomy, psychological resilience decreases.

Among the participants, resilience scores of the ones who are older have higher resilience scores compared to younger ones. There is a statistically positive significant difference on average resilience score according to age. This positive and significant difference may result from the fact that older participants are more experienced than the younger ones.

\section{Conclusions and Suggestions}

In the study, it was aimed to examine psychological resilience status of a total of 150 participants, among which 24 females (16\%) and 126 males (84), who engage in wrestling as a sports activity in the city of Antalya in terms of a variety of variables. It was identified that female participants have higher scores of psychological resilience compared to male participants. However, any significant difference between them was not found. It was also identified that there is a statistically significant and positive difference on the average psychological resilience scores of participants engaging in wrestling based on age difference. Furthermore, statistically significant and negative difference on resilience score of participants and the years they spent in wrestling as a sports activity. In terms of average resilience score of participants engaging in wrestling as a sports activity based on their educational status, it was found that the ones who do not have any education have the highest score while primary school 
graduates have the lowest. Although it is thought that the educational levels of wrestlers should be increased, it is rather interesting that the ones without any education have the highest score of resilience. In this respect, it may be beneficial to run education and sport together and to carry out activities oriented towards psychological values and life skills within the curriculum. It was observed that the resilience scores of participants engaging in wrestling who have harmful habits are higher than the ones who do not have these habits. It is known that bad habits are used for the purposes of psychological support. However, good stress management and resilience education will result in a way more positive outcomes. Thus, it is believed that stress management and resilience education for children and teenagers during their periods of education may be beneficial. It is seen that a significant majority of participants engaging in wrestling as a sports activity perceive parental attitudes as caring. Average resilience score for caring parental attitude is higher than not caring parental attitude. It may be thought that sport is associated with parents. Accordingly, caring parental attitudes will have positive contributions during childhood and teenager periods.

\section{REFERENCES}

[1] Basım, H., \& Çetin, F. (2011). Yetişkinler için psikolojik dayanıklılık ölçeği'nin güvenilirlik ve geçerlilik çalışması. Psikiyatri Dergisi, 22(2), 104-114.

[2] Bayköse N., Civar Yavuz S., Çoban M., Şahan H., Certel Z., (2016) Role of self-talk in prediction of passion level in physical education class environment. Turkısh Onlıne Journal Of Educational Technology, Special Issue , pp.445-452.

[3] Bayköse N., Civar Yavuz S., Keskin P., Kilinç M., (2017a). The Role of Self-Esteem and Passion in Determining Resilience in Athletes: An Application of Structural Equation Modelling. International Journal of Sports, Exercise and Training Science, vol.3, pp.169-177.

[4] Bayköse N., Civar Yavuz S., Şahin A., Özer Ö., (2017b). Investigation Of Healthy Living Behaviors Of University Students Participatıng And Non Participatıng Sports. Turkish Online Journal of Educational Technology, Special Issue, pp.286-292, 2017

[5] Brooks, , \& Alpay Bülbül. (2015). Tenis ve basketbol Sporcularının Pikolojik Dayanıklılı Seviyelerinin İncelenmesi ve Karşılaştırılması. İstanbul: Gediz Üniversitesi Sağlık bilimleri Enstitüsü.

[6] Brooks, R. B. (1994). Children at risk: Fostering resilience and hope. American Journal of Orthopsychiatry, 64(4), 545-553.

[7] Bülbül, A. (2015). Basketbol ve Tenis Sporcularının Psikolojik Dayanıkllık Seviyelerinin Incelenmesi Ve Karşılaştırılması. İstanbul : Gediz Üniversitesi Sağlık Bilimleri Enstitüsü.
[8] Coleman, J. C., Coleman, J., \& Hagell, A. (Eds.). (2007). Adolescence, risk and resilience: Against the odds (Vol. 3). John Wiley \& Sons.

[9] Çataloğlu, B. (2011). Madde Kullanan ve Kullanmayan Ergenlerin Psikolojik Sağlamlık Ve Aile İşlevleri Açısından Karşılaştırılması. İzmir.

[10] De Haan, L., Hawley, D. R., \& Deal, J. E. (2002). Operationalizing family resilience: A methodological strategy. American Journal of Family Therapy, 30(4), 275-291.

[11] Erdal, R. (2012). Sporda Yönetim ve Organizasyon. İstanbul: Bedra Basın Yayıncilık.

[12] Eryücel, S. (2018).Koruma Altındaki Çocuklara Yönelik Dini Manevi Rehberlik Uygulamaları İle Umut Ve Psikolojik Sağlamlık İlişkisi. Akademik Sosyal Araştırmalar Dergisi, Y11: 6, Say1: 80, Ekim 2018, S. 367-385

[13] Fletcher, D., \& Sarkar, M. (2012). A grounded theory of psychological resilience in Olympic champions. Psychology of sport and exercise, 13(5), 669-678.

[14] Fonagy, P., Steele, M., Steele, H., Higgitt, A., \& Target, M. (1994). The Emanuel Miller memorial lecture 1992 the theory and practice of resilience. Journal of child psychology and psychiatry, 35(2), 231-257.

[15] Friborg O, Barlaug D, Martinussen M et al. (2005) Resilience in Relation to Personality and Intelligence. Int $J$ Methods Psychiatr Res, 14:29-42.

[16] Garmezy, N. (1991). Resilience and Vulnerability To Adverse Developmental Outcomes Associated With Poverty. Am Behav Sci, 34:416-430.

[17] Greff, A. H. (2004). Resilience in families in which a parent has died. The American Journal of family Therapy, $32,27-42$.

[18] Haase, J. E. (2004). The adolescent resilience model as a guide to interventions. Journal of Pediatric oncology nursing, 21(5), 289-299.

[19] Hunter, A. (2001). A Cross-Cultural Comparison Of Resilience in Adolescents. J Pediatr Nurs 16, 172-179.

[20] Kılcıgil, E. (1985). Sosyal Çevre-Spor İlişkileri. Ankara: Bağıran Yayınevi.

[21] Kiliç T., Bayköse N., Kaplan K., (2018). Comparing the Life Quality of the Students in the Faculty of Sports Sciences and the Faculty of Education", Journal of Education and Training Studies, no.8, pp.116-122.

[22] Masten, A. S. (2001). Ordinary Magic Resilience Processesin Development. American Psychologist 56(3), 227-238.

[23] Olsson, P., Galaz, V., \& Boonstra, W. (2014). Sustainability transformations: a resilience perspective. Ecology and Society, 19(4).

[24] Öz, F., \& Yılmaz, E. (2009). Ruh Sağlığının Korunmasında Önemli Bir Kavram:Psikoloij Sağlamlılık. Sağlık Bilimleri Fakültesi Hemşirelik Dergisi , 82-89.

[25] Ramirez, E. (2007). Resilience: A Concept Analysis. Nursing Forum, 42, 73-82. Nursing Forum,. 
[26] Rutter, M. (2015). Resilience: concepts, findings, and clinical implications. Rutter's Child and Adolescent Psychiatry, 341-351.

[27] Smith, J., \& Prior, M. (1995). Temperament and stress resilience in school-age children: A within-families study. Journal of the American Academy of Child \& Adolescent Psychiatry, 34(2), 168-179.

[28] Tusaie, K., \& Dyer, J. (2004). Resilience: A historical review of the construct. Holistic nursing practice, 18(1), 3-10.

[29] Tümlü, G. Ü., \& Recepoğlu, E. (2013). Üniversite Akademik Personelinin Psikolojik Dayanıklılık ve Yaşam Doyumlarının İncelenmesi. Yüksek Ögretim ve Bilim Dergisi, 205-213.

[30] Wagnild, G. (2009). A review of the Resilience Scale. Journal of nursing measurement, 17(2), 105-113. 